\title{
THE EVALUATION OF IMMUNOMODULATORY ACTIVITY OF MEGANATHI KULIGAI- AN SIDDHA HERBO MINERAL COMPOUND FORMULATION IN WISTER ALBINO RATS \\ Sathiya $\mathrm{R}^{1^{*}}$, Manoharan $\mathrm{A}^{2^{* *}}$, Santhanakumar $\mathrm{M}$ \\ 1 - PG Scholar, Government Siddha Medical College \& Hospital, Palayamkottai-627002, Tirunelveli, Tamilnadu \\ 2 - Professor \& HOD, Dept. Of Poth Maruthuvam, Government Siddha Medical college \& Hospital, Palayamkottai-627002, Tirunelveli, Tamilnadu \\ 3 - Asst. Professor \& NSS Programme Officer, Dept.of Pharmacology, Arulmigu Kalasalingam College of Pharmacy, Krishnankoil,
} Srivilliputtur, Tamilnadu

Email- drsathiyar@gmail.com \& drmanoharan25@gmail.com

\section{ABSTRACT}

The Siddha formulation had a significance role against the chronic diseases, which were considered challenging to contemporary medicinal system. Core of this study is to observe of Immunomodulatory activity and evaluate the enhanced immunological response due to instruction of Non-Toxic Herbo-mineral formulation of Meganathi Kuligai on Wister Albino rats. Hemagglutination antibody titter is a primary parameter for studying the Humoral response, Antigen and antibody reaction (Th-2 pathway) in agglutination helps its secretion in plasma cells promoting formation and release of IL-4 and decreasing formation of $\mathrm{IL}-12$, the cytokine favoring Th- 1 mediating Humoral immune response and Immunostimulant activity improving general health by enhanced body's immunity.

Key words : Meganathi kuligai, Immune response, Wister albino rats, Fresh Sheep RBCs, Immunostimulant 


\section{INTRODUCTION}

Siddha system is mainly practiced in the Southern part of India. It is one of the most primitive traditional medicines in the world which focus on treatment of Body, Mind and Soul. Siddha medicines assures cure in certain disease conditions that are found to be complicated to treat by contemporary medical system. Herbo mineral preparation of Meganathi kuligai is a combination of 10 ingredients and were used for the treatment of chronic diseases. The use of plant products as an Immunomodulators is till in its developing stage. There are several herbs and minerals used in the Siddha system of medicine that may modulate the body's immune system. Meganathi kuligai, a group of Non toxic Herbomineral drug were used to improve the general health by stimulating the body's immunity.

AIM

To

evaluate

the

Immunomodulatory

activity

Meganathi kuligai an Siddha Herbomineral compound formulation in Wister albino rats.

\section{STUDY DESIGN}

Observational In-vivo study

\section{MATERIALS AND METHODS}

\section{ANIMALS}

Albino Wister rats six in number, each of $100 \mathrm{~g}$ were used in the current study. They were maintained under standard environmental conditions and were fed with standard pellet diet and water ad libitum. Fresh sheep red blood cells(SRBCs) in Alsever's solution were from Animal bred house, Dept.of Pharmacology, Arulmigu Kalasalingam College of Pharmacy, Krishnankoil, Srivilliputtur.

\section{PROCEDURE}

The effect of the test drugs on antibody formation against sheep red blood cells (SRBC) were measured as described by Doherty.The selected animals were divided into four groups of six.

The first group received distilled water, and served as the control group; the second group also received distilled water and served as SRBC control group. Calculated doses of the two samples of MK (Low and High dose) were administered for 10 consecutive days to the third and fourth groups, respectively.

On the third day, sheep blood was collected from the slaughter house in a sterilized bottle containing Alsever's solution $(2 \%$ dextrose, $0.8 \%$ sodium citrate, $0.5 \%$ citric acid, and $0.42 \%$ sodium chloride) aseptically so that agglutination of blood does not take place.

The collected sheep blood was thoroughly washed with sterile normal saline through repeated centrifugation until the supernatant fluid became colorless then it was made to $30 \%$ SRBC solution. This sensitizing agent was injected subcutaneously in the dose of $0.5 \mathrm{ml} / 100 \mathrm{~g}$ of body weight to the rats of Second to Fourth groups.

On the 11th day, the animals were weighed again and under light ether anesthesia, blood was drawn by puncturing supraorbital plexus and collected in plain tubes. Serum was separated from it and complements were inactivated by incubating it for 30 minutes at $56^{\circ} \mathrm{C}$ temperature in a serological water bath.

\section{ESTIMATION OF ANTIBODY TITER}


The Microtiter plate was filled with $0.1 \mathrm{ml}$ sterile normal saline, and up to 16 serial two-fold dilutions of $0.1 \mathrm{ml}$ serum in sterile saline solution were made in the Microtiter plate. $0.1 \mathrm{ml}$ of thrice salinewashed 3\% SRBC was added to each one of the tray.

Blood from the same animal (sheep) was used for both sensitization and to determine antibody titer. The trays were covered and placed in a refrigerator overnight. Antibody titer (Hemagglutination titer) was noted the next day. The titer was converted to log2 values for the easy comparison between groups.

\section{EFFECT ON CELL-MEDIATED IMMUNITY}

The effects were evaluated using the procedure of Bhattacharya.The selected animals were divided into three groups of six animals in each group.

First group received distilled water and served as normal control group. To the second and third groups, calculated doses of low and high were administered. All the animals were sensitized subcutaneously $10.5 \mathrm{ml} / 100 \mathrm{~g}$ body weight) on the first day of drug administration using the following solution: triple antigen (DPT) - $1 \mathrm{ml}$, normal saline $(0.9 \%)$ - $4 \mathrm{ml}$, and potash alum (10\%) - $1 \mathrm{ml}$.

The solution $\mathrm{pH}$ was maintained between 5.6 and 6.8 using $10 \%$ sodium carbonate. The drug was administered for seven consecutive days. On the seventh day, one hour after drug administration, the initial volume of the left hind paw was noted, and $0.1 \mathrm{ml}$ of the above solution was injected into plantar aponeurosis of same paw. The volume of immunological edema thus produced was measured by the volume displacement method 24 and 48 hours after the injection, using a plethysmograph.

From this the percentage increase in paw volume, the index of edema formation, was calculated.

\section{STATISTICAL ANALYSIS}

Results were presented as Mean \pm SEM, statistical significance of between groups difference was determined using unpaired Student's ' $t$ ' tests. 


\section{RESULTS}

TABLE 1

EFFECT ON ANTIBODY FORMATION

\begin{tabular}{|c|c|c|}
\hline TREATMENT & ANTI BODY( $\left.\log _{2}\right)$ & PERCENTAGE CHANGE \\
\hline SRBC CONTROL & $03.50 \pm 00.24$ & 328.571 \\
\hline M K 200 & $03.85 \pm 00.25$ & 289.610 \\
\hline M K 400 & $04.08 \pm 00.13^{*}$ & 15.110 \\
\hline
\end{tabular}

Mean \pm SEM, ${ }^{*} P<0.05$ compared with SRBC control group.

TABLE 2

EFFECT ON IMMUNOLOGICALPAW EDEMA

\begin{tabular}{|c|c|c|c|c|}
\hline \multirow{2}{*}{ TREATMENT } & \multicolumn{4}{|c|}{ PERCENTAGE INCREASE IN PAW VOLUME } \\
\cline { 2 - 5 } & $\mathbf{2 4}$ HOURS & \% INHIBITION & $\mathbf{4 8}$ HOURS & INHIBITION \\
\hline CONTROL & $46.87 \pm 9.68$ & - & $37.90 \pm 10.12$ & \\
\hline M K 200 & $28.15 \pm 05.38$ & 38.10 & $17.25 \pm 06.62$ & 368.75 \\
\hline M K 400 & $22.70 \pm 02.15^{*}$ & 49.50 & $10.16 \pm 02.60^{*}$ & 176.09 \\
\hline
\end{tabular}

Mean \pm SEM $\downarrow$ - Decrease ${ }^{*} P<0.05$ compared with control group.

Pre-treatment with MK significantly $(P<0.05)$ enhanced antibody titer [Table No. 1] in SRBC presensitized rats in comparison with the SRBC control group. Treatment with MK also enhanced antibody titer.
A normal range of body weight increase was observed in control group of rats. In contrast, an apparent decrease in body weight was observed in SRBC control rats. Pre treatment with MK has significantly attenuated the body 
weight changes compared to the SRBC control group [Table No. 2].

In the MK group, a statistically significant decrease in immunological edema was observed both after 24-hours and 48-hours.

\section{DISCUSSION}

Gain in body weight indicates normal progressive health status of an organism while decrease is indicative of degenerative changes in the body or certain organs. In the present study, presensitization of animals with SRBC led to significant decreases in body weight in 10 days. Both low and high dose formulations significantly attenuated SRBC induced body weight changes. The observed effects may be attributed to prevention of SRBC- (antigen) induced degenerative changes in the body.

Cell-mediated immunity (CMI) involves effector mechanisms carried out by $T$ lymphocytes and their products (Lymphokines). The Th-1 T-lymphocyte pathway controls cell-mediated immunity.

Hemagglutination antibody titter is a primary parameter for studying the Humoral response. Antigen and antibody reaction results in agglutination. Antibody molecules secreted by plasma cells mediate the Humoral immune response.

MK showed significantly increased in Hemagglutination titter, indicating Immunostimulant activity. Such stimulation of Humoral response to SRBC indicates enhanced responsiveness of macrophages, $T$ and $B$ lymphocyte subsets, involved in antibody synthesis SRBC may therefore stimulate lymphocyte proliferation, in turn leading to production of cytokines activating other immune cells such as B cells.

\section{CONCLUSION}

The pre-treatment of Meganathi Kuligai has significantly suppresses immunological oedema suggesting that it may suppress that pathway. At the same time it seems to influence the Th-2 pathway, as indicated by enhanced antibody formation. Such effects could be produced by promoting formation and release of IL-4, while at the same time, decreasing formation of IL-12, the cytokine favoring Th-1 mediated immune response.

\section{REFERENCES}

1.Barua CC, Gupta PP, Patnaik GK, MisraBhattacharya S, Goel RK, Kulshrestha DK, et al.

2. Tripathi RM, Das PK. Studies on antiasthmatic and antianaphylactic activity of Albizzia 2004;26:43-51.

\section{Pratibha N, Saxena VS, Amit A, D'Souza}

P, Bagchi $M$, Bagchi D. Anti-inflammatory activities of Aller-7. A novel polyherbal formulation for allergic rhinitis. Int J Tissue React 2004;26:43-51.

4. Sunila ES, Kuttan G. Immunomodulatory and Antitumor activity of Piper longum Linn and Piperine. J Ethnopharmacol 2004:90:339-46.

5. Yadav VS, Mishra KP, Singh DP, Mehrotra S, Singh VK Immunomodulatory Effects of Curcumin. Immunopharmacol Immunotoxicol 2005;27:485-97. 
6. Fulzele SV, Bhurchandi PM, Kanoje VM, Joshi SB, Dorle AK. Immunostimulant activity of Ashtamangala Ghrita in rats. Indian J Pharmacol 2002;34:194-7.

7. Liu H, Zhu Y. Effect of alcohol extract of Zingiber officinale rose on immunologic function of mice with tumor. Wei ShengYan Jiu 2002;31:208-9.

activities of Aller-7. A novel polyherbal formulation for allergic rhinitis. Int J Tissue React

8. Immunomodulatory Effect of Albizzia lebbeck. Pharm Biol 2000;38:161-6.

9. Immunomodulatory Effects of Curcumin. Immunopharmacol Immunotoxicol 2005;27:485-97.

10. Immunostimulant activity of Ashtamangala Ghrita in rats. Indian J Pharmacol 2002;34:194-7. Indian J Pharm 1977:9:189-94. Piperine. J Ethnopharmacol 2004:90:339-46. 